A Journal of Culture, English Language, Teaching \& Literature ISSN 1414-3320 (Print), ISSN 2502-4914 (Online)

$$
\text { Vol. } 19 \text { No.1; July } 2019
$$

Copyright (C) Soegijapranata Catholic University, Indonesia

Applying Metacognitive Strategies in Comprehending

English Reading Texts

${ }^{1 *}$ Zulfadli A. Aziz, ${ }^{2}$ Chairina Nasir, and ${ }^{3}$ Ramazani

${ }^{123}$ English Education Department, Faculty of Teacher Training and Education, Universitas Syiah Kuala, Banda Aceh, Indonesia

email: ${ }^{1}$ zulfadli.aziz@unsyiah.ac.id, 22hairina.nasir@unsyiah.ac.id, ${ }^{3}$ ramazani@ymail.com

Received: 01-02-2019

Accepted: 08-06-2019

Published: 31-07-2019 


\title{
Applying Metacognitive Strategies in Comprehending English Reading Texts
}

\author{
${ }^{1 *}$ Zulfadli A. Aziz, ${ }^{2}$ Chairina Nasir, and ${ }^{3}$ Ramazani \\ ${ }^{1}$ zulfadli.aziz@unsyiah.ac.id, 2 chairina.nasir@unsyiah.ac.id, \\ ${ }^{3}$ ramazani @ymail.com \\ 1,2,3 English Education Department, Faculty of Teacher \\ Training and Education, Universitas Syiah Kuala, Banda \\ Aceh, Indonesia
}

\begin{abstract}
Comprehending English text is still regarded as hard for students. Metacognitive strategies have been considered effective in overcoming reading difficulties by many researchers. The objective of this study is to describe the application of three types of metacognitive reading strategies (global strategies, problem solving strategies, and support strategies) used by the students of Senior High School (SMAN) 1 Ingin Jaya, Aceh Besar. It is a descriptive qualitative study. Metacognitive Awareness of Reading Strategies Inventory (MARSI) questionnaire suggested by Mokhtari and Reichard (2002) was used to collect the data. The result of the study revealed that the students generally showed moderate awareness of all strategies and held a preference of using Problem Solving Strategies, followed by Support Strategies and Global Strategies respectively. The study also showed that high performance students used the strategies more frequently than low performance students. It can be concluded that the more students aware of using metacognitive reading strategies, the better their performance is in reading skill. Therefore, teaching the students to use metacognitive strategies can be a solution in enhancing students' reading ability.
\end{abstract}

Key words: Reading comprehension, metacognitive reading strategies, low and high performance students

Abstrak: Memahami wacana bahasa Inggris masih dianggap sulit bagi siswa. Strategi metakognitif telah dianggap efektif dalam mengatasi 
kesulitan membaca oleh banyak peneliti. Tujuan dari penelitian ini adalah untuk menggambarkan penerapan tiga jenis strategi membaca metakognitif (strategi global, strategi pemecahan masalah, dan strategi dukungan) yang digunakan oleh siswa Sekolah Menengah Atas (SMAN) 1 Ingin Jaya, Aceh Besar. Penelitian kualitatif deskriptif ini menggunakan angket Metacognitive of Reading Strategies Inventory (MARSI) yang disarankan oleh Mokhtari dan Reichard (2002) untuk mengumpulkan data. Hasil penelitian mengungkapkan bahwa siswa umumnya menunjukkan kesadaran moderat dari semua strategi dan memiliki preferensi menggunakan Strategi Pemecahan Masalah, diikuti oleh Strategi Dukungan dan Strategi Global masing-masing. Selain itu, siswa berprestasi tinggi menggunakan strategi lebih sering daripada siswa berprestasi rendah. Dapat disimpulkan bahwa semakin sadar siswa menggunakan strategi membaca metakognitif, semakin baik kinerja mereka dalam keterampilan membaca. Oleh karena itu, mengajar siswa untuk menggunakan strategi metakognitif dapat menjadi solusi dalam meningkatkan kemampuan membaca mereka.

Kata kunci: Pemahaman membaca, strategi membaca metakognitif, rendah dan siswa berprestasi tinggi

\section{INTRODUCTION}

Teaching English in senior high schools in Indonesia aims at, among other things as stated in the English Syllabus for Senior High School levels, enabling students to read and comprehend the text in the forms of interpersonal and transactional written discourse, formal and informal functional texts, and several genres of text such as recount, narrative, descriptive, procedure, news item, factual report, analytical exposition, etc. However, based on the initial observation conducted at some schools in Banda Aceh and Aceh Besar it was found that it seems to be hard for the students in comprehending English texts. The results of several tests given by the teachers showed that most of students received unsatisfactory scores in reading comprehension. They said it was difficult for them to find the main ideas and the detailed information in the texts in a short time because they had to read and translate the text word by word. Students can actually use some strategies to develop their reading ability. Reading strategy is defined as the way of accessing the meanings of the text which are employed flexibly and selectively in the course of reading (Richard \& Schmidt, 2002, p. 444). Using reading strategies has been believed to be helpful to successfully comprehend 
passages despite the complex nature of reading process in the second language reading research (see Bernhardt, 2005; Grabe, 2004).

One of reading strategies is metacognitive strategy. It functions to monitor or regulate cognitive strategies which involve thinking about the learning process, planning for learning, monitoring of comprehension or production while the learning process is running, and evaluating of learning at the end of learning activity (Ozek \& Civelek, 2006, p. 2). Such strategy is very critical for second/foreign language readers. Ahmadi, et al. (2013, p. 235) suggest that learning metacognitive reading strategy can solve the problems faced by readers since it is the effective way to facilitate their reading comprehension in the field of English as a Foreign Language (EFL) studies.

As an important effort that students can use in improving their reading skill, the application of metacognitive strategy can be implemented differently by low performance students to result high performance ones. The results of many studies reveal that successful learners show a higher degree of metacognitive awareness, which enables them to use reading strategies more frequently than unsuccessful learners (Zhang \& Wu, 2009). It means that poor readers rarely use reading strategy, whereas it is crucial for them to improve their reading ability. It has been revealed that readers' metacognitive awareness of reading strategies is closely linked to their language proficiency (Zhang \& Seepho, 2013). Sheorey and Mokhtari (2001) examined the differences in the reported use of reading strategies of native (L1) and nonnative (L2) English speakers when reading academic materials. They found that students' reading ability was related to their metacognitive awareness and the use of reading strategy while reading, and it showed that proficient L1 and L2 readers had higher degrees of metacognitive awareness than non-proficient readers. This present study, focuses on finding out the metacognitive reading strategies used by students at a senior high school in Aceh Besar in reading comprehension. In this study, it is only focused on metacognitive strategies proposed by Mokhtari and Reichard (2002) in which they classify metacognitive strategies in three categories, namely global reading strategies, problem solving strategies, and support strategies.

\section{LITERATURE REVIEW}

In reading activities, readers are expected to comprehend the meaning of the text being read. Therefore, the main goal of reading is to extract and construct meaning from the text (see Sweet \& Snow, 2002). Comprehension 
is therefore the proficiency to understand not only the words but also the ideas in a text and the relationships that may exist between them (McNamara, 2007). In reading comprehension a complex cognitive ability is required to integrate the meaning of the text with the prior knowledge of the reader and resulting in the elaboration of a mental representation (Meneghetti, Carretti $\&$ De Beni, 2006).

Having an ability to read in every kind of reading materials is crucial for EFL students in learning English in order to acquire the excessive amounts of knowledge and information. Reading becomes a viable means of developing L2 ability that can facilitate or hinder academic success for many L2 learners across educational contexts (Gorsuch \& Taguchi, 2010). Keshavarz and Mobarra (2003) state that being able in reading is the main manifestation in learning a language because the better one can read the more learned he or she is expected to be. It can be inferred that reading is the most needed skill that students have to master in learning English. By reading, students will be able to gain much knowledge and information so that it is easier for them to master other skills in language learning.

\section{A. Language learning strategy}

Learning strategies have been described by Wenden and Rubin (1987, p. 19) as any sets of operations, steps, plans, routines used by learners to facilitate the obtaining, storage, retrieval, and use of information. These are usually applied consciously by learners and which may result in actions to improve the learning of a second or foreign language through the storage, retention, recall, and application of information about that language (Cohen, 1990, p. 4). According to Richards, Platt and Platt (1992, p. 209), learning strategies are intentional behavior and thoughts that learners use during learning in order to better enhance them understand, learn, or remember new information. Chamot and O'Malley $(1990$, p. 1) have argued that readers should use some special thoughts or behaviors in order to help them comprehend, learn, or retain new information. As the concious processes learners used in solving problems in language task (Kara, 2015, p. 20), learning strategies can be a useful means that will help learners enhance their learning.

\section{B. Reading strategy}

Reading strategies can help students in improving their reading ability. Reading strategies have been defined as specific, deliberate, goal-directed mental processes or behaviors, which control and modify the reader's efforts to decode a text, understand words and construct the meaning of a text 
142 Celt: A Journal of Culture, English Language Teaching \& Literature, Volume 19, Number 1, July 2019, pp. 138 - 159

(Afflerbach, Pearson \& Paris, 2008). According to Tovani (2000, p. 5), reading strategies are flexible intentional plans that readers use to help themselves make sense of their reading and meet the demands of the reading task. Mokhtari and Sheorey (2002) have composed three components of strategy for reading: 1) intentional, carefully planned techniques by which readers manage their reading process, 2 ) actions and procedures that the readers utilize while working directly with a text, and 3) fundamental support mechanisms intended to aid their readers in decoding the text.

Reading strategies have also been classified into three main categories, those are: cognitive strategies, metacognitive strategies, and social affective strategies (Chamot \& O'Malley, 1990). Cognitive strategies involve direct interaction with the text that contributes to facilitate comprehension, operate directly on oncoming information, and manipulate it in ways to enhance learning. Meanwhile, metacognitive strategies sequential processes that one uses to control cognitive activities. The other one is socio affective strategies which have close relationship with social-mediating activity and interacting with others.

\section{Metacognitive strategy}

Metacognitive strategies are referred to as sequential processes that people use to control cognitive activities, and to ensure that a cognitive goal has been met (Chamot \& O'Malley, 1990). Metacognitive strategies are regarded as high order executive skills that make use of knowledge of cognitive processes and constitute an attempt to regulate ones' own learning by means of planning, monitoring, and evaluating (Zhang \& Seepho, 2013). Mokharti and Reichard (2002) view metacognitive reading strategy awareness as the interest not only for what they indicate about the ways students arrange their interaction with the context, but also for how the use of strategies is related to effective reading comprehension. Mokhtari and Reichard (2002), furthermore, categorize metacognitive reading stategies into three types, those are global reading strategies, problem solving strategies, and support strategies.

According to Mokhtari and Reichard (2002), global reading strategies are the set of generalized, intentional reading strategies oriented toward a global analysis of text that aim at setting the stage for the reading act and thoroughly planned techniques readers use to monitor their reading (e.g., setting purpose for reading, previewing the structure of the text, and making prediction). Problem solving strategies, on the other hand, are the localized and focused strategies which appear to be oriented toward solving problems 
when a text becomes difficult to read. Problem solving are also the actions which readers utilize in the process of working directly with the text. Support strategies, in Mokhtari and Reichard's (2002) view, are fundamental support mechanisms to help readers undertand the text (e.g using of outside reference materials, using dictionary, taking notes) and other practical strategies that might be described as functional or support strategies.

\section{The effectiveness of metacognitive strategy in reading}

Metacognitive strategies in reading are those strategies that are designed to increase readers' knowledge of awareness and control. When faced with reading difficulties in reading comprehension, learners tend to use some metacognitive strategies to cope with these difficulties (Wen, 2003). Phan (2006) says that metacognitive processes have been understood to play an essential part in achieving comprehension. Sheorey and Mokhtari (2001) also believe that knowing the metacognitive strategies and being aware of the strategies used may aid students to be responsive as well as to be able to construct meaning from the text.

\section{RESEARCH METHOD}

This descriptive qualitative research analyzed and described the application of metacognitive reading strategies conducted by low and high performance students based on the framework of MARSI adapted from Mokhtari and Reichard (2002). It was conducted at Senior Haigh School (SMA) 1 Ingin Jaya, Greater Aceh. This school is one of the excellent schools in Aceh Besar which is equipped with good facilities. The subject of this study was the students of the third grade that was class XIIA $_{1}$. In selecting the sample, the purposive sampling was used which means that these students were selected because of some aims. The students were divided into two groups, namely high performance students and low performance students. They were classified according to the mean score they got from daily reading tests given by their teacher. The students who had reached the minimal passing grade of 75 were in the high performance student group; meanwhile, the students who had not reached the score were classified into the low performance group.

The data were obtained through distributing Metacognitive Awareness of Reading Strategies Inventory (MARSI) questionnaire designed by Mokhtari and Reichard (2002) to the students in order to find out the types of 
144 Celt: A Journal of Culture, English Language Teaching \& Literature, Volume 19, Number 1, July 2019, pp. $138-159$

metacognitive reading strategies applied by high performance students and low performance students and how often they use the certain types of strategies. The questionnaire consists of 30 statements which were translated into Bahasa Indonesia related to the types of metacognitive reading strategies (e.g. global reading strategies, problem solving strategies, and support reading strategies), and each statement was accompanied by a-5 point Likert-type scale. The data were then analyzed based on the scoring rubric of Metacognitive Awareness of Reading Strategies Inventory (MARSI).

\section{RESULTS}

A. The application of metacognitive reading strategies used by all students

The total number of respondents filled out the questionnaire were 28 students, in which 6 were males and 22 were females. Their ages ranged from 16-18. From the results of the questionnaire it shows the students' mean scores of overall and each subscales of reading strategies which indicated how often they use the strategies (overall strategies, global reading strategies (GLOB), problem solving strategies (PROB), and support reading srategies (SUP)). The averages of overall strategies of each student were resulted from the total scores for all statements divided by the number of overall strategies. Likewise, the averages of three sub-categories of metacognitive strategies counted by dividing the sum of scores by the number of statements for each subscales as presented in Table 1 below.

Table 1:

Students' mean scores of the use of overall and three sub-categories of metacognitive strategies

\begin{tabular}{ccccc}
\hline Students & Overall Score & GLOB Score & PROB Score & SUP Score \\
\hline Std 1 & 2.5 & 2.0 & 3.8 & 2.2 \\
\hline Std 2 & 2.4 & 2.1 & 2.5 & 2.9 \\
\hline Std 3 & 2.5 & 2.3 & 2.8 & 2.6 \\
\hline Std 4 & 2.3 & 2.0 & 2.6 & 2.3 \\
\hline Std 5 & 2.6 & 2.6 & 3.0 & 2.3 \\
\hline Std 6 & 2.5 & 1.8 & 3.0 & 3.0 \\
\hline Std 7 & 3.0 & 2.7 & 3.8 & 2.9 \\
\hline Std 8 & 3.5 & 3.2 & 3.9 & 3.6 \\
\hline Std 9 & 2.7 & 2.4 & 2.5 & 3.4 \\
\hline
\end{tabular}



Comprehending English Reading Tests

\begin{tabular}{lllll}
\hline Std 10 & 3.5 & 3.2 & 3.8 & 3.9 \\
\hline Std 11 & 3.2 & 2.3 & 4.1 & 3.7 \\
\hline Std 12 & 3.6 & 3.4 & 4.4 & 3.2 \\
\hline Std 13 & 2.3 & 2.2 & 2.5 & 2.4 \\
\hline Std 14 & 4.0 & 4.2 & 4.1 & 3.7 \\
\hline Std 15 & 3.9 & 3.2 & 4.3 & 4.4 \\
\hline Std 16 & 2.5 & 2.5 & 3.6 & 1.7 \\
\hline Std 17 & 2.2 & 1.7 & 3.0 & 2.3 \\
\hline Std 18 & 2.4 & 2.2 & 2.8 & 2.6 \\
\hline Std 19 & 3.1 & 2.9 & 3.5 & 3.1 \\
\hline Std 20 & 1.5 & 1.5 & 1.6 & 1.4 \\
\hline Std 21 & 3.4 & 3.2 & 3.4 & 3.7 \\
\hline Std 22 & 2.4 & 2.0 & 2.6 & 2.7 \\
\hline Std 23 & 3.5 & 3.2 & 3.8 & 3.7 \\
\hline Std 24 & 3.3 & 3.4 & 3.6 & 3.0 \\
\hline $\operatorname{Std} 25$ & 2.4 & 2.1 & 2.5 & 2.8 \\
\hline Std 26 & 3.6 & 3.4 & 3.8 & 3.8 \\
\hline Std 27 & 2.9 & 2.6 & 3.1 & 3.0 \\
\hline Std 28 & 4.1 & 4.4 & 3.4 & 4.4 \\
\hline
\end{tabular}

From the table above, it shows that the students got varied mean scores of metacognitive strategy usage which means that each student used the strategies in different frequency. Based on the mean scores got by students as shown in the table above, they can be classified into three categories of metacognitive strategy use; those are low, medium, and high. As determined by Mokhtari and Reichard (2002) in scoring rubric of MARSI, those who got the mean score 2.4 or lower were classified into low which means that they used the metacognitive strategies at least usage. If the mean score got was 2.5 to 3.4, it means that ones used these strategies at medium usage. Furthermore, those who got mean score 3.5 or higher was classified into high usage of metacognitive strategies.

According to this standard, therefore, the students can be classified into the three groups (low, medium, high) based on their mean scores obtained from the questionnaires. Table 2 shows the classification of students' overall strategies usage. Studying the table, it can be inferred from the table that from the total of 28 students, 8 students $(28.6 \%)$ were grouped into low usage, 12 students $(42.8 \%)$ were grouped into medium usage, and 8 students $(28.6 \%)$ were grouped into high usage. Generally, the result reveals that most of students (71.4\% students from high and medium group) have had good metacognitive awareness of reading strategies which means that they tend to 
146 Celt: A Journal of Culture, English Language Teaching \& Literature, Volume 19, Number 1, July 2019, pp. $138-159$

use the metacognitive strategies frequently to cope with their problems in reading. However, there were still a number of students who showed low awareness of reading strategy in which leads them to rarely use strategies while reading.

Table 2:

Students' Overall Strategies Usage

\begin{tabular}{ccc}
\hline Students & Overall Score & Classification \\
\hline Std 1 & 2.5 & Medium \\
\hline Std 2 & 2.4 & Low \\
\hline Std 3 & 2.5 & Medium \\
\hline Std 4 & 2.3 & Low \\
\hline Std 5 & 2.6 & Medium \\
\hline Std 6 & 2.5 & Medium \\
\hline Std 7 & 3.0 & Medium \\
\hline Std 8 & 3.5 & High \\
\hline Std 9 & 2.7 & Medium \\
\hline Std 10 & 3.5 & High \\
\hline Std 11 & 3.2 & Medium \\
\hline Std 12 & 3.6 & High \\
\hline Std 13 & 2.3 & Low \\
\hline Std 14 & 4.0 & High \\
\hline Std 15 & 3.9 & High \\
\hline Std 16 & 2.5 & Medium \\
\hline Std 17 & 2.2 & Low \\
\hline Std 18 & 2.4 & Low \\
\hline Std 19 & 3.1 & Medium \\
\hline Std 20 & 1.5 & Low \\
\hline Std 21 & 3.4 & Medium \\
\hline Std 22 & 2.4 & Low \\
\hline Std 23 & 3.5 & High \\
\hline Std 24 & 3.3 & Medium \\
\hline Std 25 & 2.4 & Low \\
\hline Std 26 & 3.6 & High \\
\hline Std 27 & 2.9 & Medium \\
\hline Std 28 & 4.1 & High \\
\hline & & \\
\hline
\end{tabular}

Apart from overall reading strategies, there are also average scores of each student for the three sub-categories of metacognitive reading strategies. Statistically, the sum of all items' mean scores for each sub-category divided by the number of items in each category results the mean scores of each type of 
strategies (global reading strategies, problem solving strategies, and support strategies). Consequently, this result indicates the most favorable subcategories of strategies used by the students as presented in Table 3 below

Table 3:

Students' preference in using the three sub-categories of metacognitive strategies

\begin{tabular}{cc}
\hline Types of Strategies & Mean \\
\hline PROB & 3.27 \\
SUP & 3.02 \\
GLOB & 2.66 \\
\hline
\end{tabular}

The Table 3 above shows that the highest mean score was in problem solving strategies which automatically means that the students preferred to use this type mostly, followed by support strategies and global reading strategies. It can be said that generally when facing problems in reading, students used problem solving strategies frequently to overcome the problems as well as supported by support reading strategies and global reading strategies.

The percentage of students' usage of metacognitive reading strategies as explained before, the results from MARSI questionnaire also showed the most and least frequency of each metacognitive reading strategy used by students. The result obtained from the mean score of each statement was represented from the total scores of each statement divided by the total number of students. The detail results were listed in the table below.

Table 4:

Frequency of metacognitive reading strategies used the most and the least

\begin{tabular}{l|c}
\hline \multicolumn{1}{c|}{ Strategy } & Mean \\
\hline $\begin{array}{l}\text { When text becomes difficult, I pay closer attention to what I'm } \\
\text { reading. (PROB) }\end{array}$ & 3.82 \\
\hline $\begin{array}{l}\text { I use reference materials such as dictionaries to help me understand } \\
\text { what I read. (SUP) }\end{array}$ & 3.75 \\
\hline $\begin{array}{l}\text { I read slowly but carefully to be sure I understand what I'm reading. } \\
\text { (PROB) }\end{array}$ & 3.68 \\
\hline I try to get back on track when I lose concentration. (PROB) & 3.68 \\
\hline $\begin{array}{l}\text { When text becomes difficult, I re-read to increase my understanding. } \\
\text { (PROB) }\end{array}$ & 3.50 \\
\hline I have a purpose in mind when I read. (GLOB) & 3.25 \\
\hline I discuss what I read with others to check my understanding. (SUP) & 3.25 \\
\hline
\end{tabular}


148 Celt: A Journal of Culture, English Language Teaching \& Literature, Volume 19, Number 1, July 2019, pp. 138 - 159

\begin{tabular}{|c|c|}
\hline $\begin{array}{l}\text { I underline or circle information in the text to help me remember it. } \\
\text { (SUP) }\end{array}$ & 3.18 \\
\hline $\begin{array}{l}\text { I paraphrase (restate ideas in my own words) to better understand } \\
\text { what I read. (SUP) }\end{array}$ & 3.18 \\
\hline $\begin{array}{l}\text { I think about what I know to help me understand what I read. } \\
\text { (GLOB) }\end{array}$ & 3.14 \\
\hline I try to guess the meaning of unknown words or phrases. (PROB) & 3.07 \\
\hline $\begin{array}{l}\text { When text becomes difficult, I read aloud to help me understand } \\
\text { what I read. (SUP) }\end{array}$ & 3.04 \\
\hline I take notes while reading to help me understand what I read. (SUP) & 3.04 \\
\hline I preview the text to see what it's about before reading it. (GLOB) & 3.04 \\
\hline $\begin{array}{l}\text { I go back and forth in the text to find relationships among ideas in } \\
\text { it. (SUP) }\end{array}$ & 2.96 \\
\hline $\begin{array}{l}\text { I try to picture or visualize information to help remember what I } \\
\text { read. (PROB) }\end{array}$ & 2.96 \\
\hline $\begin{array}{l}\text { I check to see if my guesses about the text are right or wrong. } \\
\text { (GLOB) }\end{array}$ & 2.89 \\
\hline $\begin{array}{l}\text { I check my understanding when I come across conflicting } \\
\text { information. (GLOB) }\end{array}$ & 2.79 \\
\hline I stop from time to time and think about what I'm reading. (PROB) & 2.75 \\
\hline I adjust my reading speed according to what I'm reading. (PROB) & 2.68 \\
\hline I decide what to read closely and what to ignore. (GLOB) & 2.64 \\
\hline $\begin{array}{l}\text { I think about whether the content of the text fits my reading } \\
\text { purpose. (GLOB) }\end{array}$ & 2.64 \\
\hline $\begin{array}{l}\text { I skim the text first by noting characteristics like length and } \\
\text { organization. (GLOB) }\end{array}$ & 2.57 \\
\hline I try to guess what the material is about when I read. (GLOB) & 2.57 \\
\hline $\begin{array}{l}\begin{array}{l}\text { use tables, figures, and pictures in text to increase my } \\
\text { understanding. (GLOB) }\end{array} \\
\end{array}$ & 2.54 \\
\hline I ask myself questions I like to have answered in the text. (SUP) & 2.50 \\
\hline $\begin{array}{l}\text { I summarize what I read to reflect on important information in the } \\
\text { text. (SUP) }\end{array}$ & 2.32 \\
\hline $\begin{array}{l}\text { I critically analyze and evaluate the information presented in the } \\
\text { text. (GLOB) }\end{array}$ & 2.21 \\
\hline $\begin{array}{l}\text { I use typographical aids like bold face and italics to identify key } \\
\text { information. (GLOB) }\end{array}$ & 2.14 \\
\hline $\begin{array}{l}\text { I use context clues to help me better understand what I'm reading. } \\
\text { (GLOB) }\end{array}$ & 2.14 \\
\hline
\end{tabular}

The average score for each statement indicated how often the students use each strategy for the MARSI questionnaire while reading English texts. As explained before, three levels of usage were identified low (average score of 2.4 or lower), medium (average score of 2.5 to 3.4), and high (average score of 3.5 
or higher). The statistical result as presented in table 4.4 above revealed that 5 of the 30 strategies (16.7\%) fell in the high usage group, 21 strategies $(70 \%)$ had mean scores between 2.5 and 3.25 which indicated medium usage of these strategies, and only 4 strategies (13.3\%) were reported to be used with low frequency (mean scores below 2.4). This shows that the respondents mostly displayed medium awareness of metacognitive reading strategies.

According to Table 4, the most metacognitive reading strategy used by the students was "when text becomes difficult, I pay closer attention to what I'm reading" as problem solving strategy. Moreover, "I use reference materials such as dictionaries to help me understand what I read" was the second most used of reading strategies applied by the students as support strategies. Additionally, three of the strategies which is classified as problem solving strategies followed the two aforementioned strategies as the top five of the strategies used most; those were "I read slowly but carefully to be sure I understand what I'm reading", "I try to get back on track when I lose concentration", and "when text becomes difficult, I re-read to increase my understanding".

From the five strategies which is classified into high usage (mean $=3.50$ 3.82) as well as used most by the students, four out of the five strategies mentioned were problem solving strategies and only one was support strategies. This result is consistent with the fact that problem solving strategy was the most favorite strategy used by students as explained before. Related to this result, it revealed that when the problems arose in reading, the students frequently used 1) problem solving strategies such as paying closer attention to the text, 2) reading slowly but carefully, 3) trying to get back when losing concentration, and 4) re-reading the text. It can be concluded that the students need more time available when reading because they are concentrating on the text to comprehend it by reading slowly and carefully, as well as when losing concentration, they are trying to get back to the text by rereading the text. In addition, they also applied support strategies which was using dictionaries to help them understand the text. Because the students had problems in vocabulary mastery, dictionaries may be the essential aids for them in translating unknown vocabulary or phrases into Bahasa Indonesia so that they got the meaning of the text. Therefore, setting much more time for reading can be a solution to let students applied those strategies and as a result they are able to comprehend the English texts well.

It can be inferred from the findings that there were strategies which were identified as the least used. The bottom five metacognitive strategies used were 
"I use context clues to help me better understand what I'm reading", "I use typographical aids like bold face and italics to identify key information", "I critically analyze and evaluate the information presented in the text", "I summarize what I read to reflect on important information in the text", and "I ask myself questions I like to have answered in the text."

Four out of the bottom five metacognitive strategies used fell in the low usage which had a mean score between 2.14 and 2.32 and only one strategy that was classified into medium usage (mean score 2.50). Furthermore, the three lowermost strategies were global strategies while two of the remaining strategies were support strategies. Tthis is in line with the previous finding that global strategies and support strategies had lower mean score compared to problem solving strategies. It also indicates that the students rarely used global reading strategies particularly using context clues, using typographical aids to identify key information, and analyzing and evaluating the information in the text critically.

Students regard that it is hard to use context clues to comprehend the text because they did not really understand what the context clues itself is. Besides, finding the key information in the text, it is also considered difficult by the students because it is an effect of their limited vocabulary, thus, they hardly ever used typographical aids to identify key information as a reading strategy. Analyzing and evaluating the information in the text critically was applied infrequently by the students since this strategy seems complicated for them to do. The other two support strategies which were summarizing the text and asking themselves questions to be answered in the text indicated occasionally employed by the students when they are reading. It can be concluded that the students had not mastered these strategies to assist them in comprehending English text so that they have to learn about those strategies and use them when reading.

\section{B. The application of metacognitive reading strategies used by low and high performance students}

The application of metacognitive reading strategies applied by low and high performance students is revealed in the data analysis. There were 15 low performance students and 13 high performance students which henceforth were linked to their application of metacognitive strategies (see Table 2 above which indicates the classification of students' overall strategies usage). The following two tables presents the classification of overall metacognitive reading strategies usage applied by low performance students and high performance 
students respectively. According to the tables there is a difference of the average scores obtained by low and high performance students.

In Table 5, the students' mean scores were between 1.5 and 3.0 which means that they applied metacognitive reading strategies in low and medium usage. From the total number of low performance students which were 15 students, 8 students (53.3\%) fell into low usage, whereas 7 students $(46.7 \%)$ fell into medium usage with average scores 2.5-3.0. It shows that most of these students got low mean scores, whereas, there was none of the students, who got high mean scores. It means that these students were not ready to adopt metacognitive reading strategies in understanding English texts and it was the cause for the metacognitive awareness of applying reading strategies to low performance students, which is still far from the expectations of the teacher.

\section{Table 5:}

The application of overall metacognitive reading strategies used by low performance students

\begin{tabular}{ccc}
\hline Students & Mean & Classification \\
\hline Std 1 & 2.5 & Medium \\
\hline Std 2 & 2.4 & Low \\
\hline Std 3 & 2.5 & Medium \\
\hline Std 4 & 2.3 & Low \\
\hline Std 5 & 2.6 & Medium \\
\hline Std 6 & 2.5 & Medium \\
\hline Std 7 & 3.0 & Medium \\
\hline Std 13 & 2.3 & Low \\
\hline Std 16 & 2.5 & Medium \\
\hline Std 17 & Low \\
\hline Std 18 & 2.2 & Low \\
\hline Std 20 & 2.4 & Low \\
\hline Std 22 & 1.5 & Low \\
\hline Std 25 & 2.4 & Low \\
\hline Std 27 & 2.4 & Medium
\end{tabular}

In contrast to Table 5 , Table 6 shows the mean scores received by high performance students which had a range between 2.7 and 4.1. It indicates that they applied metacognitive reading strategies in medium and high usage. Only 5 of 13 students $(38.5 \%)$ were reported, however, to apply in medium usage, where the remaining 8 students $(61.5 \%)$ fell into high usage. Interestingly, none of the high performance students were grouped in low usage. It means 
152 Celt: A Journal of Culture, English Language Teaching \& Literature, Volume 19, Number 1, July 2019, pp. 138 - 159

that high performance students not only got good scores in reading but also they tend to got high mean scores in this inventory which showed that they were aware to use metacognitive reading strategies when the difficulties in reading appeared.

Table 6:

The application of overall metacognitive reading strategies used by high performance students

\begin{tabular}{ccc}
\hline Students & Mean & Classification \\
\hline Std 8 & 3.5 & High \\
\hline Std 9 & 2.7 & Medium \\
\hline Std 10 & 3.5 & High \\
\hline Std 11 & 3.2 & Medium \\
\hline Std 12 & 3.6 & High \\
\hline Std 14 & 4.0 & High \\
\hline Std 15 & 3.9 & High \\
\hline Std 19 & 3.1 & Medium \\
\hline Std 21 & 3.4 & Medium \\
\hline Std 23 & 3.5 & High \\
\hline Std 24 & 3.3 & Medium \\
\hline Std 26 & 3.6 & High \\
\hline Std 28 & 4.1 & High \\
\hline
\end{tabular}

of the research also makes use of the MARSI questionnaire, which revealed that the application of metacognitive reading strategies used by low performance students differs from high performance students. Although both groups fell into medium usage, none of the low performance students used the strategies in high usage. On the contrary, none of the high performance students reported to use the strategies in low usage. In line with this, it can be argued that high performance students showed high awareness of metacognitive strategies which leads them to use reading strategies frequently, whereas low performance students find it hard to use those strategies in enhancing their reading proficiency. It suggests that the students' awareness of applying metacognitive reading strategies is closely linked to their reading proficiency. Therefore, those who have problems in reading can take into consideration to apply metacognitive reading strategies since these strategies will be effective to assist them to cope with the problems likeexperienced by the high performance students. 
Table 7:

Low and high performance students' preference in using the three subcategories of metacognitive strategies

\begin{tabular}{c|c|c}
\hline Students & Types of Strategies & Mean \\
\hline \multirow{3}{*}{ Low Performance Students } & PROB & 2.88 \\
\cline { 2 - 3 } & SUP & 2.47 \\
\cline { 2 - 3 } & GLOB & 2.14 \\
\hline \multirow{3}{*}{ High Performance Students } & PROB & 3.72 \\
\cline { 2 - 3 } & SUP & 3.66 \\
\cline { 2 - 3 } & GLOB & 3.26 \\
\hline
\end{tabular}

The mean scores of overall strategies obtained by students can be analyzed further by using the three sub-scales of strategies (global strategies, problem solving strategies, and support strategies) result, which weremostly used by the students. The following table 8 and 9 presents both low and high performance students' favorite types of strategies.

\section{Table 8:}

Frequency of metacognitive reading strategies used the most and the least by low performance students

\begin{tabular}{l|l}
\hline \multicolumn{1}{c|}{$\begin{array}{c}\text { Top Five Metacognitive Reading } \\
\text { Strategies }\end{array}$} & \multicolumn{1}{|c}{$\begin{array}{c}\text { Bottom Five Metacognitive Reading } \\
\text { Strategies }\end{array}$} \\
\hline $\begin{array}{l}\text { I use reference materials such as as } \\
\text { dictionaries to help me understand } \\
\text { what I read. (SUP) }\end{array}$ & $\begin{array}{l}\text { I critically analyze and evaluate the } \\
\text { information presented in the text. } \\
\text { (GLOB) }\end{array}$ \\
\hline $\begin{array}{l}\text { I try to get back on track when I lose } \\
\text { concentration. (PROB) }\end{array}$ & $\begin{array}{l}\text { I use typographical aids like bold face } \\
\text { and italics to identify key information. } \\
\text { (GLOB) }\end{array}$ \\
\hline $\begin{array}{l}\text { When text becomes difficult, I pay } \\
\text { closer intention to what I'm reading. } \\
\text { (PROB) }\end{array}$ & $\begin{array}{l}\text { I use context clues to help me better } \\
\text { understand what I'm reading. (GLOB) }\end{array}$ \\
\hline $\begin{array}{l}\text { I try to guess meaning of unknown } \\
\text { words or phrases. (PROB) }\end{array}$ & $\begin{array}{l}\text { I summarize what I read to reflect on } \\
\text { important information in the text. } \\
\text { (SUP) }\end{array}$ \\
\hline $\begin{array}{l}\text { I read slowly but carefully to be sure I I } \\
\text { understand what I'm reading. (PROB) }\end{array}$ & $\begin{array}{l}\text { I discuss what I read with others to } \\
\text { check my understanding. (SUP) }\end{array}$ \\
\hline
\end{tabular}

It can be inferred from the table above that both low and high performance students seem to prefer using problem solving strategies rather 
154 Celt: A Journal of Culture, English Language Teaching \& Literature, Volume 19, Number 1, July 2019, pp. 138 - 159

than support strategies and global strategies even though these two groups attained different mean scores for each type of strategies. It shows that high performance students obtained higher mean scores than low performance students for each type. It is an agreement with the findings explained in previous section that generally all students prefered to use problem solving strategies followed by support strategies and global strategies. It also demonstrates that high performance students tend to get higher mean scores than low performance students not only for overall strategies but also for the three sub-categories of metacognitive strategies. Considering the types of strategies preferred by the students, the strategies used most and least by both groups of students can be also analyzed by adding up the score of each statement, and then divided by the total number of students from each group. The following tables show the strategies used most and least by both groups of students the in more detail.

Table 9:

Frequency of reading strategies used the most and the least by high performance students

\begin{tabular}{l|l}
\hline \multicolumn{1}{c|}{$\begin{array}{c}\text { Top Five Metacognitive Reading } \\
\text { Strategies }\end{array}$} & $\begin{array}{l}\text { Bottom Five Metacognitive Reading } \\
\text { Strategies }\end{array}$ \\
\hline $\begin{array}{l}\text { I read slowly but carefully to be sure I } \\
\text { understand what I'm reading. (PROB) }\end{array}$ & $\begin{array}{l}\text { I use tables, figures, and pictures in the } \\
\text { text to increase my understanding. } \\
\text { (GLOB) }\end{array}$ \\
\hline $\begin{array}{l}\text { When text becomes difficult, I pay } \\
\text { closer intention to what I'm reading. } \\
\text { (PROB) }\end{array}$ & $\begin{array}{l}\text { I stop from time to time and think } \\
\text { about what I'm reading. (PROB) }\end{array}$ \\
$\begin{array}{l}\text { When text becomes difficult, I re-read } \\
\text { to increase my understanding. (PROB) }\end{array}$ & $\begin{array}{l}\text { I summarize what I read to reflect on } \\
\text { important information in the text. } \\
\text { (SUP) }\end{array}$ \\
$\begin{array}{l}\text { When text becomes difficult, I read } \\
\text { aloud to to help me understand what I } \\
\text { read. (SUP) }\end{array}$ & $\begin{array}{l}\text { I try to guess that the material is about } \\
\text { when I read. (GLOB) }\end{array}$ \\
\hline $\begin{array}{l}\text { I use reference materials such as } \\
\text { dictionaries to help me understand } \\
\text { what I read. (SUP) }\end{array}$ & $\begin{array}{l}\text { I check to see if my guesses about the } \\
\text { text are right or wrong. (GLOB) }\end{array}$ \\
\hline
\end{tabular}

The two tables above revealed that both low and high performance students used such strategies mostly as using reference materials (dictionaries), paying closer attention to the text and reading slowly but carefully to understand the text. However, high performance students were helped by re- 
reading the text and reading aload when text becomes difficult, while low performance students tend to try to get back when losing concentration and guessing unknown words or phrases. The strategies used most by low performance students seem to be almost the same with high performance students which means that those strategies were helpful for them. Though, the frequency of using these strategies was significantly different for both of groups.

The differences can be seen in applying the least used strategies. The low performance students had difficulty in analyzing and evaluating information critically, identifying key information, using context clues, summarizing the text, and rarely discuss with others for better understanding. The high performance students are seen occasionally using tables, figures, and pictures in the text, stopping from time to time to think about the text, summarizing the text, guessing the material, and checking the guesses about whether or not the text is right or wrong.

From the explanation above, it can be summarized that in applying the metacognitive reading strategies, low and high performance students preferred the same type of having problem solving strategies. This supported the reading strategies and global reading strategies.

\section{DISCUSSION}

Reading is one of the four language skills which has to be mastered by students in achieving their English learning goals at school,which answers the curriculum's demands. Mastering this skill will not only be useful for students' achievements in learning English formally, but also it is essential in their daily life to access the richness of information. However, comprehending English texts is still considered hard by most students as a consequence of their lack of vocabulary mastery and grammar knowledge. Applying reading strategies can be taken into consideration to have good impact for students so that they are able to comprehend English text. Among the strategies, metacognitive reading strategies are believed to be the effective aids in helping students to overcome their problems in reading.

As informed earlier, the resaerch $s$ found that the strategies used by the students were problem solving strategies such as paying closer intention to the text, reading slowly but carefully to be sure, trying to get back when losing concentration, and re-reading for better understanding. This result coincides 
with the findings in Genc (2011, p. 654) who studied the reading strategies used by low proficient EFL learners in Turkey. They found that the problem solving strategies especially for the statements stated above fell into the high usage and were most frequently used by the students. Furthermore, using reference materials (dictionaries) to increase understanding as support strategies which also fell in the high usage was considered as the top five mostly used strategy is in accordance with Genc's (2011, p. 654) study.

The findings also indicated that the least frequently used strategies in which fell into low usage were global strategies. However, compared to support strategies, global strategies was in the lowest position. The students were not ready to adopt some strategies like using context clues, identifying key information, critically analyzing and evaluating text, summarizing text, and asking self questions in solving their difficulties in reading. This result is a little bit different with Genc's (2011, p. 654) in which they found that support strategies were the least frequently used compared to global strategies. One possible explanation of this difference can be the result of different culture, teachers, motivation, personality, and so on. Nevertheless, the two stated studies' findings above that the lowest usage of critically analyzing the text and asking self questions are in line with this present study.

Generally, based on statistical result, it showed that high performance students were better in showing metacognitive awareness which made them to use the strategies more frequently than low performance students. Although they tend to use the same types, however, it indicated a significant dissimilarity in frequency. This result was supported by Zhang \& Wu (2009) who stated that successful learners showed a higher degree of metacognitive awareness, which led them to use reading strategies more efficiently than unsuccessful learners. In addition, Sheorey and Mokhtari (2001) also added that proficient readers showed higher degrees of metacognitive awareness than non-proficient readers which enabled them to use more strategies. Moreover, in her study, Kara $(2015$, p.20) revealed that in overcoming the problems in the text, proficient readers applied more strategies.

Based on the explanation above, the fact that high performance students showed higher degree of metacognitive awareness which enabled them to use the strategies more frequently than low performance students, to revealthat reading proficiencywas positively related to metacognitive awareness of using reading strategies, was in accordance with Zhang and Seepho's research. Like Zhang and Seepho's (2013) this study indicated that there was a significant 
positive correlation between metacognitive strategy use and English reading achievement.

Referring to all the facts explained before, applying metacognitive reading strategies in reading has been proven to be an effective solution in overcoming problems in reading that may appear. This result has been supported by Sheorey and Mokhtari (2001) who believed that knowing the metacognitive strategies and being aware of the strategies used may aid students to comprehend the text. Phan (2006) also supported that metacognitive strategies play an essential part in achieving comprehension.

\section{CONCLUSION}

The MARSI questionnaire revealed that most students have applied metacognitive reading strategies in high and medium usage rather than low usage. From the total number of students, 8 students $(28.6 \%)$ showed high usage, 12 students (42.8\%) fell into medium usage, and 8 students $(28.6 \%)$ had low mean scores which indicated they were in low usage. The most favorable of three sub-scales of metacognitive reading strategies used by all students was problem solving strategies, followed by support strategies and global strategies respectively. This article also that high performance students tend to show higher degree of metacognitive awareness which assist them to use reading strategies more frequently than low performance students. In addition, both low and high performance learners preferred to use problem solving strategies, followed by support strategies and global strategies respectively even though they showed significantly different results in the frequency of using those strategies.

\section{REFERENCES}

Afflerbach, P., Pearson, P. D., \& Paris, S. G. (2008). Clarifying differences between reading skills and reading strategies. The Reading Teacher, 61, 364-373.

Ahmadi, M. R., Ismail, H. N., \& Abdullah, M. K. (2013). The Importance of Metacognitive Reading Strategy Awareness in Reading Comprehension. English Language Teaching, 6 (10), 235-244. 
Bernhardt, E. (2005). Progress and procrastination in second language reading. Annual Review of Applied Linguistics, 25, 133-150.

Chamot, A. U. \& O’Malley, J. M. (1990). Learning Strategies in Second Language Acquisition. Oxford: Oxford University Press.

Cohen, A. (1990). Language Learning: Insights for Learners, Teachers, and Researchers. New York: Newbury House.

Genc, H. (2011). Paper and Screen: Reading Strategies Used by Low-Proficient EFL Learners. Sino-US English Teaching , 8 (10), pp. 648-658.

Gorsuch, G., \& Taguchi, E. (2010). Developing Reading Fluency and Comprehension Using Repeated Reading: Evidence from Longitudinal Student Reports. Language Teaching Research, 14(1), 27-59.

Grabe, W. (2004). Research on Teaching Reading. Annual Review of Applied Linguistics, 24, 44-69.

Kara, S. (2015). Reading Strategies: Prospective Teachers and Their Teaching Practices. Journal of Educational and Instructional Studies In the World, 5 (3), 20-28

Keshavarz, M. \& Mobarra, M. (2003). The Effects of Simplification and Elaboration on Reading Comprehension of Iranian EFL Learners. Iranian Journal of Applied Linguistics, 6 (1), 101-117.

McNamara, D. S. (2007). Reading comprehension strategies: Theories, interventions and technologies. Mahwah, NJ: Lawrence Erlbaum Associates.

Meneghetti, C., Carretti, B. \& De Beni, R. (2006). Components of Reading Comprehension and Scholastic Achievement. Learning and Individual Differences, 16, 291-301.

Mokhtari, K. \& Reichard, C. (2002). Assessing Students' Metacognitive Awareness of Reading Strategies. Journal of Educational Psychology, 94 (2), 249-259.

Ozek, Y., \& Civelek, M. (2006). A Study on The Use of Cognitive Reading Strategies by ELT Students. The Asian EFL Journal, 1-26.

Phan, N. (2006). Effective reading. Retrieved on April 10, 2015 from http://www.asian-efl-journal.com/pta_march_14_np.php 
Aziz, Z.A. Nasir, C. \& Ramazani, Applying Metacognitive Strategies in

Comprehending English Reading Tests

Richards, C. \& Schmidt, R. (2002). Longman Dictionary of Language Teaching and Applied Linguistics. $3^{\text {rd }}$ Edition. London: Pearson Education Limited.

Richards, J. C., Platt J. \& Platt H. (1992). Longman Dictionary of Language Teaching and Applied Linguistics. Essex: Longman.

Sheorey, R., \& Mokhtari, K. (2001). Differencess in The Metacognitive Awareness of Reading Strategies Among Native and Non-Native Readers. System, 29, 431-449.

Sweet, A. P. \& Snow, C. (2002). Reconceptualizing Reading Comprehension. In C. C. Block, L. B. Gambrell, M. Pressley (Eds.), Improving Comprehension Instruction (pp. 17-53). San Francisco, CA: Jossey-Bass.

Tovani, C. (2000). I Read It, But I Don't Get It: Comprehension Strategies for Adolescent Readers. Portland, Maine: Stenhouse Publishers.

Wen, Q. F. (2003). The Successful Way of Learning English. Shanghai: Shanghai Foreign Language Education Press.

Wenden, A. L. \& Rubin, J. (1987). Learner Strategies in Language Learning. Englewood Cliffs, NJ: Prentice Hall.

Zhang, L. \& Seepho, S. (2013). Metacognitive Strategy Use and Academic Reading Achievement: Insights from a Chinese Context. Electronic Journal of Foreign Language Teaching , 10 (1), 54-69.

Zhang, L. J. \& Wu, A. (2009). Chinese Senior High School EFL Students' Metacognitive Awareness and Reading-Strategy. Reading in a Foreign Language, 21(1), 37-59. 